Conditions of effectiveness of methods of supporting women's psychological well-being in situations

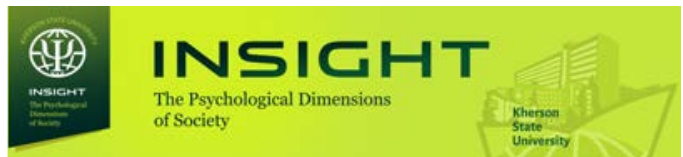

DOI: $10.32999 / 2663-970 X / 2020-3-8$

Link article (Style APA): Saveikiene, D. \& Volodarska, N. D. (2020). Conditions of effectiveness of methods of supporting women's psychological well-being in situations of temporary relocation. Insight: the psychological dimensions of society, 3, 109-121. DOI: 10.32999/2663-970X/2020-3-8

Link article (Style DSTU 8302: 2015): Saveikiene, D. \& Volodarska, N. D. Conditions of effectiveness of methods of supporting women's psychological well-being in situations of temporary relocation. Insight: the psychological dimensions of society, 2020, 3, 109-121. D0I: 10.32999/2663-970X/2020-3-8

UDC 59.923.2:314.15-022.326

\title{
Conditions of effectiveness of methods of supporting women's psychological well-being in situations of temporary relocation
}

\author{
Умови ефективності методів підтримки психологічного \\ благополуччя жінок в ситуаціях тимчасового переселення
}

\author{
Received: April 06, 2020 Accepted: May 12, 2020
}

\author{
Saveikiene Diana \\ candidate of psychological sciences, \\ PhD student \\ Klaipeda University, Lithuania \\ dianasaveik@gmail.com \\ ORCID 0000-0003-4179-3879 \\ Volodarska Nataliia Dmytrivna \\ Candidate of Psychological Sciences \\ Senior Researcher, Leading Researcher \\ G. S. Kostuk Institute of Psychology \\ of the National Academy of Educational \\ Sciences of Ukraine, Ukraine \\ volodarskaya@ukr.net \\ ORCID 0000-0003-1223-718X
}

\author{
Савейкіене Діана \\ кандидат психологічних наук, докторант \\ Клайпедський університет, Литва \\ dianasaveik@gmail.com \\ ORCID 0000-0003-4173-3879 \\ Володарська Наталія Дмитрівна \\ кандидат психологічних наук, \\ старший науковий співробітник, \\ провідний науковий співробітник \\ Інститут психології імені Г. С. Костюка \\ НАПН України \\ volodarskaya@ukr.net \\ ORCID 0000-0003-1223-718X
}

\begin{abstract}
Purpose. The article presents the research of problems of psychological assistance to women in temporary resettlement. Methods. Dialogue-phenomenological method, interviews, art-therapeutic methods: common drawings, "Wreath of Memories". Results. The relevance of the research of the problem of individual's psychological well-being in crisis situations is outlined. The urgent problems of psychological assistance to women temporary migrants who have undergone changes in social conditions are highlighted. Theoretical and methodological approaches to the problem of recovering and maintaining the psychological well-being of the individual
\end{abstract}

\section{Анотація}

Мета. Вивчення проблем психологічної допомоги жінкам, що опинились в умовах тимчасового переселення. Методи. Діалогово-феноменологічний метод, інтерв'ю, арт-терапевтичні методики: спільні малюнки, «Віночок спогадів». Результати. Окреслена актуальність дослідження проблеми психологічного благополуччя особистості в кризових ситуаціях. Виділені нагальні проблеми психологічної допомоги жінкам тимчасовим переселенцям, які перенесли зміни соціальних умов. Визначаються теоретико-методологічні підходи до проблеми відновлення та підтримки 
are determined. The influence of psychological defense mechanisms of the personality on the social adaptation in the conditions of temporary resettlement is described. The particularities of application of group and individual psychotherapy techniques for activating the development of psychological well-being of personality are described. Conclusions. The effectiveness of techniques for emotional state psycho correction of temporarily resettled persons has been studied. It is determined that mobilization of women to the direct manifestations of their feelings, desires in dialogue with other persons, which intensifies their implementation, is an important condition for the effectiveness of the applied methods. Awareness and realization of these desires, openness in the manifestation of their desires, the manifestation of restrained emotions forms confidence in relationships with others, helps to maintain their own mental and physiological integrity. Possibilities of combination and use of art-therapeutic techniques and dialogue-phenomenological gestalt approach are determined. Recommendations for the organization of psychological assistance to women in recovering their psychological well-being are given. Means of conducting techniques for reducing emotional stress of the personality are selected. The analysis of obstacles in the social adaptation of the personality in crisis situations is carried out. The obtained empirical results of the study will contribute to effective organization of psychological support.

Keywords: adaptation, psychological well-being, gestalt therapy, fairytale therapy, group therapy, psychological defenses.

\section{Introduction}

In conditions of temporary resettlement of people arising as a result of the military conflict in Ukraine, the problem of psychological support is exacerbated. People get a traumatic experience. They experience states that cause instability, as well as loss of control over situation, their own lives, loss of autonomy and subjectivity, identity disturbances, confusion, psychosomatic disorders, and social adaptation disorders.

The social adaptation of women remains a special problem. Alienation and distrust in solving problems with employment, living arrangements, children's education (choice of educational institutions, kindergartens) is increasing. There is a need to develop new methods of psychotherapeutic effects to support the psychological well-being of women in situation of temporary resettlement.

The experience of domestic psychologists in psychological support to victims of extreme психологічного благополуччя особистості. Описано вплив психологічних захистів особистості на соціальну адаптацію особистості в умовах тимчасового переселення. Описані особливості застосування методів групової та індивідуальної психотерапії в активізації розвитку психологічного благополуччя особистості. Висновки. Досліджено ефективність проведення методик психокорекції емоційного стану на особах, що тимчасово переселені. Визначено, що важливою умовою ефективності застосованих методів $є$ налаштування жінок на прямі прояви своїх почуттів, бажань в діалозі 3 іншими, що активізує їхню реалізацію. Усвідомлення і реалізація цих бажань, відкритість в прояві своїх бажань, прояв утриманих емоцій формує впевненість в стосунках з іншими, допомагає зберегти власну психічну та фізіологічну цілісність. Визначені можливості поєднання і використання арт-терапевтичних методик та діалогово-феноменологічного гештальт підходу. Надані рекомендації щодо організації психологічної допомоги жінкам у відновленні їхнього психологічного благополуччя. Підібрані засоби ведення методик зниження емоційної напруги особистості. Проведений аналіз перепон у соціальній адаптації особистості у кризових ситуаціях. Отримані емпіричні результати дослідження сприятимуть ефективній організації психологічної підтримки.

Ключові слова: адаптація, психологічне благополуччя, гештальт терапія, казкотерапія, групова терапія, психологічні захисти.

\section{Вступ}

В умовах тимчасового переселення людей, що виникають внаслідок військового конфлікту в Україні, загострюється проблема психологічної підтримки. Люди набувають травматичного досвіду, переживають стани, які спричиняють нестабільність і втрату контролю над ситуацією та власним життям, втрату автономності та суб'єктності, порушення ідентичності, розгубленість, психосоматичні розлади, порушення соціальної адаптації.

Особливою проблемою залишається соціальна адаптація жінок. Збільшується відчуженість і недовіра у вирішенні проблем 3 працевлаштуванням, облаштуванням місця проживання, освітою дітей (вибором освітніх закладів, садочків). Виникає потреба розробки нових методів психотерапевтичних впливів на підтримку психологічного благополуччя 


\section{Conditions of effectiveness of methods of supporting women's psychological well-being in situations of temporary relocation}

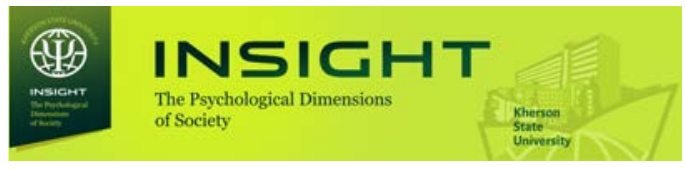

events in Ukraine covers aspects of experiencing crisis traumatic situations by different categories of victims: adults and children; experience of the hotline service; problems of psychological support to volunteers; use of mass media as a space for psychological support to the population (Kisarchuk, 2017).

Many studies show the presence of unproductive types of reflection of these persons, which can be considered as a manifestation of psychological defence mechanisms in psycho traumatic situation (Balabanova, 2017). It is concluded that psychological support to internal migrants should be aimed at the development of systemrelated reflection, as the most productive type of reflection. The impact of the stress of "hybrid" war on human mental and physical health is investigated, and recommendations for adaptation to stress of victims of military conflict have been developed (Kovalenko, 2017). Particular attention is paid to children, and ways to help children affected by the war conflict are identified. The social identity is studied as a mechanism of adaptation of personality during the social crisis. The characteristics of displaced person (a person who voluntarily left his/her country as a result of hostilities and violence related to a threat to life and health and needs support) are identified.

Following certain features of the emotional state of personality, which was in a crisis situation (specific worldview, depression of mental functions, presence of psychological trauma inherent in individuals who have experienced extreme situations), the principles were selected. According to these principles the techniques for recovery and support to psychological well-being were chosen. Feelings, personal experiences that arise in the process of their application were identified as the basis of the most important tool of methods. Differentiation of these experiences, feelings and emotions creates a field of interaction wherein the process of conceptualization of these relationships takes place. It is based on the phenomenological principle of intentionality. The mind or consciousness of person is understood as an intention and is not separated from the content that is thought or intended. This principle is embedded in the techniques of crosscultural therapy (Peseshkian, 1999).

One of the principles of techniques selection is based on the phenomenon of resiliency that is жінок, які перебувають в умовах тимчасового переселення.

Досвід вітчизняних психологів психологічної допомоги постраждалим внаслідок екстремальних подій в Україні охоплює аспекти переживання кризових травматичних ситуацій різними категоріями постраждалих: дорослими, дітьми; досвід роботи служби «Телефон довіри»; проблеми психологічної підтримки волонтерів; використання мас-медіа як простору психологічної допомоги населенню (Кисарчук, 2017). Показано наявність у цих осіб непродуктивних типів рефлексії, що може розглядатись як прояв психологічних захисних механізмів у психотравмуючій ситуації (Балабанова, 2017). Зроблено висновок, що психологічна допомога, яка надається вимушеним переселенцям, повинна спрямовуватись на розвиток системної рефлексії як найбільш продуктивного типу рефлексії. Досліджено вплив стресу «гібридної» війни на психічне та фізичне здоров'я людини, розроблені рекомендації щодо адаптації до стресу постраждалих у військовому конфлікті (Коваленко, 2017). Особлива увага приділяється дітям, визначаються шляхи допомоги дітям, що постраждали внаслідок воєнного конфлікту. Досліджується соціальна ідентичність як механізм адаптації особистості під час суспільної кризи. Визначаються особливості вимушеного переселенця, особи, яка добровільно покинула свою країну в результаті військових дій, насильства, пов'язаними із загрозою для життя і здоров'я, та потребує допомоги.

Досліджуючи особливості емоційного стану особистості, яка опинилась у кризовій ситуації (специфічне світосприйняття, пригніченість психічних функцій, наявність психологічного травмування, притаманного індивідам, що пережили екстремальні ситуації), були виділені принципи, за якими підбирались методики відновлення та підтримки психологічного благополуччя. За основу найголовнішого інструменту методик були визначені почуття, переживання особистості, які виникають в процесі їхнього застосування. Диференціація цих переживань, відчуттів, емоцій створює певний контекст взаємодії, в якому відбувається процес концептуалізації цих взаємин. В основу покладений феноменоло- 
an ability to maintain a stable level of psychological and physiological activity in adverse life situations, absence of persistent disorders and adaptation to adverse conditions. We relied on 4 aspects of mental resource (according to Gordon Newfeld, 2012): hope (self-belief that life's difficulties can be overcome); optimism (expectation that everything will end positively); resilience (do not give up and move on to peculiar goal); adaptability (ability to adapt to changes in the environment). These aspects are actualized in the process of discussion of experiences in the group of participants after performing exercises and techniques. The discussion method is based on a dialog model of interaction.

In the recovery of the psycho-emotional state of personality, his /her activity is important. This activity should be aimed at awareness of own actions, internal states, feelings, experiences, analysis of these states and formulation of appropriate conclusions. The reflection process includes structural components of individual's self-observation and introspection. Methods of activation of action of these components enable the individual to express himself/herself in a new social environment through reflection (selfawareness) of experiences, comparison of his/her current state with the image of own expectations, goals and experiences.

In the process of discussing experiences, feelings and emotions, members of the group differentiate the psychological defenses of the individual. It is those psychological defenses that the personality uses in crisis situations, in situations of conflict which can lead to neurosis. Sublimation as a psychological protection is also used, along with nine most commonly used means of psychological defense (regression, repression, reactive formations, isolation, denial, self-projection, projection, introjection, reversion). Means of psychological protection become a psychological manifestation of adaptive capabilities not only at present, but also of individual's adaptation to the future, his/ her intended prospects (Volodarska, 2019). The cognitive subsystem includes the individual's idea of own existence, while the emotional one includes the dominant emotional background in relation to various aspects of own life. Positive emotional mood may indicate the subjective wellbeing of a personality (Shamionov, 2012). гічний принцип інтенціональності. Розум або свідомість людини розуміється як інтенція і не відділяється від змісту, який мислиться або інтенціюється. Цей принцип закладений в методах кросс-культурної терапії (Пезешкиан, 1999).

Один $з$ принципів відбору методик заснований на феномені резилентності - здатності збереження стабільного рівня психологічної та фізіологічної діяльності в несприятливих життєвих ситуаціях, відсутності стійких порушень та адаптації до несприятливих умов. Ми спирались на виділені 4 аспекти психічного ресурсу: надія (впевненість в собі, що можна подолати життєві труднощі); оптимізм (очікування, що все закінчиться позитивно); стійкість (не здаватись і йти далі до своєї мети); адаптованість (здатність пристосовуватись до змін у середовищі) (Ньюфельд, 2012). Ці аспекти актуалізуються в процесі обговорення в групі переживань учасників після виконання вправ, методик. Метод обговорення спирається на діалогову модель взаємодії. У відновленні психоемоційного стану особистості важлива її діяльність, що спрямована на усвідомлення своїх дій, внутрішніх станів, відчуттів, переживань, аналіз цих станів та формулювання відповідних висновків. У процес рефлексії входять структурні компоненти самоспостереження особистості та самоаналіз. Методи активізації дії цих компонентів надають можливість особистості самовизначитись в новому соціальному оточенні через рефлексію (самоусвідомлення) переживань, порівняння свого актуального стану з образом своїх очікувань, ціледосягнень, своїх переживань.

У процесі обговорення переживань, почуттів, прояву емоцій членами групи диференціюються психологічні захисти особистості. Саме ті психологічні захисти, якими особистість користується в кризових ситуаціях, в ситуаціях конфліктів, які здатні призвести до неврозу. Сублімація як психологічний захист теж використовується, як і дев'ять найбільш вживаних засобів психологічного захисту (регресія, пригнічення, реактивні утворення, ізоляція, заперечення, звертання на себе, проекція, інтроекція, реверсія). Засоби психологічного захисту стають психологічним проявом адаптаційних можливостей не тільки сьогодення, але й пристосування особистості до майбутнього, її 


\section{Conditions of effectiveness of methods of supporting women's psychological well-being in situations of temporary relocation}

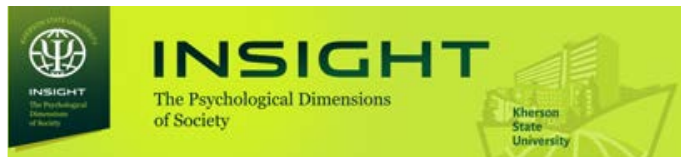

Migrants are affected by changes in social environment, new rules, standards of behavior adopted in that environment. Consideration of features of personality adaptation in the social environment, wherein the individual resides, is the basic principle of integrity in the cross-cultural cognitive therapy (McMallin, 2002). Culture determines most of the personality cognitions. This is what he/she believes and denies, how much he/she is willing to share with someone else for his/her family, what values he/she considers important and is the cause of own problems. Particular role in maintaining the integrity of family relations, the family is given to women. The possibilities of recovering and maintaining the psychological well-being of women in conditions of temporary resettlement have been insufficiently studied.

\section{Hypothesis}

It is assumed that the conditions for the effectiveness of methods to support the psychological well-being of women in situations of temporary resettlement are the activation of the process of differentiation and awareness of their own emotions, experiences, needs and forms of their manifestation; application of these conditions will contribute to the effective organization of psychological support.

The purpose and the research issue. Therefore, considering the relevance of the identified problem, the purpose of the study is to identify features of maintaining and recovering the psychological well-being of personality who is in conditions of temporary resettlement. The object of research is the means of recovering the psycho-emotional state of women temporarily displaced.

The research issue: 1. Analyze theoretical and methodological approaches to the problem of effectiveness of the conditions of the psychological well-being support to women who are temporarily resettled as a result of military conflict.

2. Investigate the effectiveness of selected means of recovering and maintaining psychological well-being.

\section{Methodology and methods}

We have considered the methodological aspects in the study of possibilities of maintaining the psychological well-being of personality in a crisis situation (Serdyuk, 2017). Appropriation бажаних перспектив (Володарська, 2019). Когнітивна підсистема включає в собі уявлення особистості про власне буття, емоційна ж домінуючий емоційний фон відносно різних аспектів свого життя. Позитивний емоційний настрій може свідчити про суб'єктивне благополуччя особистості (Шаміонов, 2012).

Переселенці потерпають від зміни соціального оточення, нових правил, норм поведінки, що прийняті в цьому оточенні. Розгляд особливостей адаптації особистості в соціальному середовищі, в якому знаходиться людина, $\epsilon$ основним принципом цілісності в кроскультурній когнітивній терапії (МакМаллин, 2002). Культура детермінує більшість з когніцій особистості. Це те, у що вона вірить і заперечує, на скільки вона готова ділитись 3 чужим для її сім'ї, які цінності вона вважає важливими і що вважає причиною її проблем. Особлива роль в збереженні цілісності сімейних відносин, родини відводиться саме жінці. Недостатньо досліджені можливості відновлення та підтримки психологічного благополуччя жінок в умовах тимчасового переселення.

Отже, зважаючи на актуальність визначеної проблеми, метою дослідження $є$ визначення особливостей підтримки та відновлення психологічного благополуччя особистості, яка опинилась в умовах тимчасового переселення. Об'єкт дослідження - засоби відновлення психоемоційного стану жінок, тимчасово переселених. Завдання дослідження: 1. Проаналізувати теоретико-методологічні підходи до проблеми ефективності умов психологічної підтримки психологічного благополуччя жінок, які тимчасово переселені у наслідок військового конфлікту. 2. Дослідити ефективність відібраних засобів відновлення та підтримки психологічного благополуччя.

Отже, зважаючи на актуальність визначеної проблеми.

Гіпотеза. Припускається, що умовами ефективності методів підтримки психологічного благополуччя жінок в ситуаціях тимчасового переселення $\epsilon$ активізація процесу диференціації та усвідомлення власних емоцій, переживань, потреб і форм їх прояву; застосування цих умов сприятиме ефективній організації психологічної підтримки.

\section{Методологія та методи дослідження}

Методологічні аспекти у дослідженні можливостей підтримки психологічного благо- 
of own experiences, feelings of respondents occurs under conditions of construction of desirable. The image of the situation contains: person's thoughts; an activity in accordance with the purpose specified in this situation; sensory activity in comprehension of features of this situation, their value to the personality. In the process of appropriation by the personality of these components of the situation image, an excitation of the individual activity occurs. It determines its focus on transformation, projection of own psychological well-being.

The dialogue-phenomenological method was a basic method of research, providing for description of the psycho-emotional state of woman, aimed at differentiation of her experiences, feelings, emotions and their further awareness and acceptance of new forms of their manifestation. Further the complex of techniques was selected according to the purpose and subject of research. Determination of the current needs of women in temporary resettlement provided an opportunity to choose techniques for support of their psychological well-being. Discussions, questioning, structured interviews were carried out, as well as group and individual psychotherapeutic techniques were applied.

The techniques provided intensification of the process of awareness of women's own desires, feelings, and experiences in the context of group interaction. This logic of urgent needs determination of the personality in crisis situations and activation of experiences manifestation was confirmed in the effectiveness of selected techniques.

\section{Participants}

The study involved 120 women aged 25 to 45 who were in temporary resettlement (who received psychological support under the project of the Program of Cooperation and Assistance to Democracy Development initiated by the Embassy of the Republic of Lithuania in Ukraine "Promoting the Social Integration of Victims of Conflict in the East of Ukraine" (No. P2019-VB-UK-18 dated 25.04.2019) during 2019 year.

\section{Procedures and instruments}

Meetings with women were held every 3 months for 3 days in Kyiv and for 5 days in the summer recreation camp in Klaipeda (Republic of Lithuania) in 2019. The first stage получчя особистості у кризовій ситуації (Сердюк, 2017) нами взяті до уваги. Привласнення своїх переживань, почуттів респондентів відбувається за умов побудови бажаного. В образі ситуації містяться: думки людини, ії активність відповідно визначеної мети в цій ситуації, почуттєва активність у засвоєнні особливостей цієї ситуації, цінності для особистості. У процесі привласнення особистістю цих складових образу ситуації відбувається збудження активності особистості, що зумовлює її спрямованість на перетворення, проектування свого психологічного благополуччя.

Основним методом дослідження був діалогово-феноменологічний метод, який передбачав опис психоемоційного стану жінки, що спрямовувався на диференціацію їі переживань, відчуттів, емоцій та подальше їхнє усвідомлення і прийняття нових форм їхнього прояву. Далі підібрано комплекс методик згідно мети і предмету дослідження. Визначення актуальних потреб жінок в умовах тимчасового переселення надало можливість підібрати методики підтримки їхнього психологічного благополуччя. Проводились дискусії, опитування, структуроване інтерв'ю, групові та індивідуальні психотерапевтичні методи.

Методики забезпечили активізацію процесу усвідомлення власних бажань, почуттів, переживань жінок у контексті групової взаємодії. Така логіка визначення нагальних потреб особистості в кризових ситуаціях i активізація прояву переживань знайшла підтвердження в ефективності підібраних методик.

Учасники. У дослідженні приймали участь 120 жінок, віком від 25 до 45 років, які опинились в умовах тимчасового переселення, (яким надавалась психологічна допомога в рамках виконання проекту Програми Розвитку співпраці і допомоги демократії від Посольства Литовської Республіки в Україні “Сприяння соціальній інтеграції громадян, які постраждали від конфлікту на Сході України" (№ P2019-VB-UK-18 від 25.04.2019р.) упродовж 2019 p.

Процедура та інструменти. Зустрічі з жінками проводились з інтервалом раз на 3 місяця по 3 дні в м. Києві і 5 днів у літньому таборі відпочинку в м. Клайпеда (Республіка Литва) 


\section{Conditions of effectiveness of methods of supporting women's psychological well-being in situations of temporary relocation}

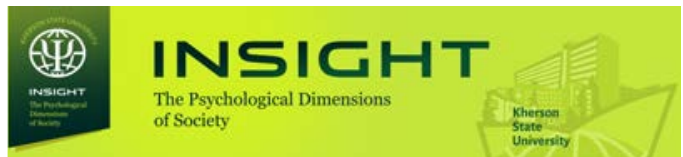

of the study was to determine the current needs for psychological support and recovery of the psychological well-being of women in conditions of temporary resettlement. The second stage included group meetings with application of therapeutic techniques.

The group exercises were: method of acquaintance through own stories, memories, discussion of emotional state of each participant. Art-therapeutic methods were: common drawing of a positive event celebration, creation of "Wreath of Memories", creation of a fairy tale for positive feelings of psychological well-being. The complex of techniques was aimed at recovery and support to the psychological well-being.

\section{Results and discussions}

The method of awareness and acceptance of phenomena arising in interaction with the social environment ensures recovery of personal sensitivity to own needs. Technically, in the process of dialogue, this task is intermediated through the phenomenological method. How does this happen? The personality in a crisis situation has problems that are difficult to solve without psychological support and assistance. When seeking for assistance, the personality presents own problem.

In dialogue with other person, the phenomena of interaction (experiences, associations, desires, etc.) are in the focus of attention. The dynamics of these phenomena is subject to the principle of closure (Prägnanz), when the most relevant (regardless of the level of awareness) experience of the personality supports a certain phenomenon to a greater extent than other experiences. This is how the figure and certain context of interaction emerge, where other phenomena of dialogue are their background.

Participants' support for their sensitivity to this process becomes important in dialogue. It is assumed that the therapeutic interaction increases the awareness level of own feelings and desire of participants in the dialogue. Working to reduce the anxiety of the personality in relationships with other persons, it takes place the learning related to rest, relax, clarification of own needs and attitude to them.

Methods of psychological presence, openness of the participants of the dialogue are the basis of technologies for accompaniment в 2019 році. Першим етапом дослідження було визначення актуальних потреб в психологічній підтримці та відновленні психологічного благополуччя жінок в умовах тимчасового переселення. Другим етапом були групові зустрічі з застосуванням терапевтичних методик. Групові вправи: метод знайомств через власні історії, спогади, обговорення емоційного стану кожного учасника. Арт-терапевтичні методи: спільний малюнок святкування позитивної події, створення "Віночка спогадів", створення казки на позитивні відчуття психологічного благополуччя. Комплекс методів спрямовувався на відновлення та підтримку психологічного благополуччя.

\section{Результати та дискусії}

Метод усвідомлення та прийняття феноменів, що виникають у взаємодії з соціальним оточенням, забезпечує відновлення чуттєвості особистості до своїх потреб. Технічно в процесі діалогу ця задача опосередковується феноменологічним методом. Яким чином це відбувається? У особистості в кризовій ситуації виникають проблеми, які важко вирішити без психологічної підтримки, допомоги. Звертаючись за допомогою, особистість представляє свою проблему. В діалозі з іншими, у фокусі уваги виникають феномени взаємодії (переживання, асоціації, бажання і т. інше). Динаміка цих феноменів підпорядковується принципу прегнантності, коли найбільш актуальне (незалежно від рівня усвідомленості) переживання особистості підтримує певний феномен більшою мірою, ніж інші переживання. Так виникає фігура, певний контекст взаємодії, фоном якої виступають інші феномени діалогу. Важливим в діалозі стає підтримка учасниками своєї чуттєвості до цього процесу. Передбачається, що в терапевтичній взаємодії збільшується рівень усвідомлення своїх переживань і бажань учасниками діалогу. Працюючи над зниженням тривоги особистості в стосунках з іншими, відбувається навчання відпочивати, розслаблятися, проясняти свої потреби, ставлення до них. В основі технологій супроводу феноменів діалогу закладений метод психологічної присутності, відкритості учасників діалогу. Ці феномени, як факти свідомості, належать контексту контактування, а не лише самій особистості. Ті переживання, 
of the dialogue phenomena. These phenomena, as facts of consciousness, belong to the context of contact and not just to a personality. Those experiences, feelings, desires, thoughts, emotions, fantasies that arise in the dialogue belong to the process of contact. Presence of personality in the dialogue is realized in support and accompaniment of emerging phenomena of interaction, enabling their existence and support to their transformations in everyday life.

Based on the theory of Gestalt approach, the methods of the dialogue model are aimed at activating the individual's interest to new thoughts, behavioral strategies, life prospects that arise in the interaction (Lebedeva, 2002). Then, it becomes important the growing ability to wander about new things and changes, that replaces control over conventional behavioral strategies.

Harmonization of all components of mental and physiological state of person contributes to his/her integrity. The experience psychotherapy does not focus on substance in a dialogue. Not words spoken in the dialogue are important, but the possibility of experiencing these words and meanings. The dialogue partners restore the psycho-emotional state in the dialogue process not due to the dynamics of topics and discoveries that occur in this process, but due to the experience of being sensual, conscious, with a free choice of life.

This confirmed the ranking of answers of women in the interview. The first task was to write positive and negative factors of the effect of resettlement to a new place of residence. Based on specified factors, the most significant problems of temporary relocation were generalized and formulated, and the task was set to rank specified difficulties of relocation conditions and conditions of assistance determined by significance. When asked "What did, in your opinion, help you, when moving to a new place?", the answer "I was supported by communication with people like us" was in the first place.

Similarly, when asked "What was the worst thing related to your migration?" women put in the first place the following answer: "Change in usual circle of contacts".

So, communication and interaction with other persons was the main factor influencing the change in the place of residence of women. Just in the group communication the sociosituational anxiety and women's fears decrease; почуття, бажання, думки, емоції, фантазії, які виникають в діалозі, належать самому процесу контактування. Присутність особистості в діалозі реалізується в підтримці і супроводі виникаючих феноменів взаємодії, в наданні можливості їхнього існування та підтримки їхньої трансформацій в повсякденному житті. Спираючись на теорію гештальт-підходу, методи діалогової моделі спрямовані на активізацію інтересу особистості до нових думок, стратегій поведінки, життєвих перспектив, які виникають у взаємодії (Лебедева, 2002). Тоді важливим стає зростаюча здатність особистості дивуватись новому, змінам, що заміщує контроль над усталеними стратегіями поведінки.

Гармонізація усіх складових психічного, фізіологічного стану людини сприяє їі цілісності. Психотерапія переживання не ставить акцент в діалозі на зміст. Важливі не слова, які проговорюються в діалозі, а те, наскільки можливе переживання цих слів, смислів. Співбесідники відновлюють психоемоційний стан в процесі діалогу не за рахунок динаміки тем і відкриттів, що відбуваються в цьому процесі, а за рахунок досвіду бути чуттєвим, усвідомлюваним, 3 вільним власним життєвим вибором.

Це підтвердило ранжування відповідей жінок в інтерв'ю. Першим завданням було написати позитивні і негативні фактори впливу переселення на нове місце проживання. На основі визначених факторів були узагальнені і сформульовані найбільш значущі проблеми тимчасового переселення та поставлене завдання ранжувати визначені за значущістю труднощі умов переселення і умови допомоги.

На питання: “Що на Вашу думку вам допомогло при переселенні на нове місце?” на першому місці була відповідь "Мене підтримало спілкування з такими, як ми".

Так само на питання «Що найгірше для Вас було у Вашому переселенні?» жінки на перше місце поставили - "Зміна звичного кола спілкування".

Отже, найголовнішим фактором впливу на зміну проживання жінок стало спілкування, взаємодія з іншими. Саме у спілкуванні в групі знижується соціально-ситуативна тривога, страхи жінок, відновлюється їхній 


\section{Conditions of effectiveness of methods of supporting women's psychological well-being in situations of temporary relocation}

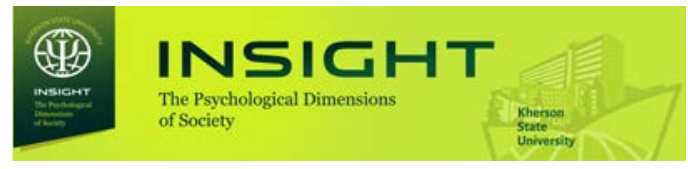

Table 1. Relevant support factors in a resettlement crisis $(\mathrm{n}=120)$

Таблиця 1. Значущі фактори підтримки у кризовій ситуації переселення $(\mathrm{n}=120)$

\begin{tabular}{|c|c|}
\hline $\begin{array}{c}\text { I was supported by communication } \\
\text { with people like me } \\
\text { Мене підтримало спілкування } \\
\text { з такими, як ми }\end{array}$ & $55,0 \%$ \\
\hline $\begin{array}{c}\text { New job } \\
\text { Hoва робота }\end{array}$ & $25,0 \%$ \\
\hline $\begin{array}{c}\text { New place of residence } \\
\text { Нове місце проживання }\end{array}$ & $5,0 \%$ \\
\hline $\begin{array}{c}\text { New perspectives for mе and my family } \\
\text { Hові перспективи для мене і моєї сім'ї }\end{array}$ & $15,0 \%$ \\
\hline
\end{tabular}

and the psycho-emotional state is recovered. In the process of discussion by women of factors that affect support to their psychological well-being, the disclosure of own resources and manifestation of own desires and needs occur. In the conditions of resettlement, the presence of the personality in crisis life situations, the construction of its dialogue with the social environment becomes a form of solving its problems. Considering the specified factors of psychological support, the psychotherapeutic techniques were selected.

Through projective techniques (common drawing of happy events' celebration "Festive Table", "Dinner", "Birthday", etc.) some attitudes to the situation were manifested. It could be ambivalent feelings of both joy and sadness (joyful feelings related to celebration and regret for lost opportunities to celebrate with all family members, relatives, former neighbors). In the course of common drawing, the quality of communication was important: contacts to each other, request to share pencils, paints, place on paper (common sheet of paper of large size). In order to activate communication, boxes with paints and brushes were given one set less than the number of participants. This encouraged participants sharing them. Manifestations of participants' requests, their irritation, anger, feelings, etc. were monitored. Objectification of these manifestations during discussion made it possible to restore participants' sensitivity to their own needs. Those things that were not previously realized and were ignored, suddenly took on a different value.

Participants discovered for themselves the renewal of feeling of tenderness in the memories of how they celebrated their
Table 2. Distribution of relevant factors in migration crisis situation $(\mathrm{n}=120)$ Таблиця 2. Розподіл значущих факторів у кризовій ситуації переселення $(\mathrm{n}=120)$

\begin{tabular}{|c|c|}
\hline $\begin{array}{c}\text { Change in usual circle of contacts } \\
\text { Зміна звичного кола спілкування }\end{array}$ & $52,0 \%$ \\
\hline $\begin{array}{c}\text { Fear of uncertainty in the present } \\
\text { Страх невизначеності у сьогоденні }\end{array}$ & $25,0 \%$ \\
\hline $\begin{array}{c}\text { Fear of losing usual job } \\
\text { Страх втрати звичної роботи }\end{array}$ & $15,0 \%$ \\
\hline $\begin{array}{c}\text { Fear of changes in normal life } \\
\text { Страх змін Звичного життя }\end{array}$ & $8,0 \%$ \\
\hline
\end{tabular}

психоемоційний стан. У процесі обговорення жінками факторів, що впливають на підтримку їхнього психологічного благополуччя, відбувається розкриття власних ресурсів, прояв власних бажань, потреб. В умовах переселення, перебування особистості в кризових життєвих ситуаціях саме побудова її діалогу з соціальним оточенням стає формою вирішення ії проблем. 3 огляду на виділені фактори психологічної підтримки були підібрані психотерапевтичні методи.

Проводячи проективні методи (спільне малювання святкування радісних подій “Святковий стіл”, “Вечеря”, “День народження” та інші), відбувались прояви певних ставлень до ситуації. Це могли бути амбівалентні почуття - і радості, і печалі. Радісні почуття до святкування і скорбота по втраченим можливостям святкувати з усіма своїми близькими людьми, родичами, колишніми сусідами. Під час спільного малювання важливим була якість спілкування: звернення один до одного, прохання поділитись олівцями, фарбами, місцем на папері (спільний лист великого розміру). В цілях активізації спілкування були видані коробки з фарбами, пензлики на один набір менше, ніж кількість учасників. Це спонукало учасників ділитись ними. Відслідковувались прояви прохань учасників, їхнє роздратування, злість, переживання і таке інше. Об'єктивація цих проявів в процесі обговорення дала можливість відновити чуттєвість учасників до власних потреб. Те, що не усвідомлювалось раніше та ігнорувалося, раптом набувало іншого значення.

Учасниці відкривали для себе відновлення почуття ніжності у спогадах того, як святкували 
birthdays, arrival of spring, New Year, pleasant feelings of "the first snow", "summer warm rain", "spring thaw". The participants were amazed that they were so "thawed" during the drawing process. According to the participants, "hard memories fill their souls", in such conditions it is difficult to enjoy simple things that happen every day. Memories from childhood about "gentle touch of flower", "warm air on the face" restored the sense of calm and sense of psychological wellbeing. Even the drawing process itself brought back to pleasant memories: "cloudless childhood" for some persons; "teenage discoveries", "romantic youth", "first kisses" for other persons. Communication in the course of drawing provoked a variety of emotions, including negative ones. The participants were angry that "even here it is necessary to fight for a place on paper". When drawing a festive table, some participants tried to fill the whole place on paper, cover with sketches every corner. Their comments indicated high socio-situational anxiety ("when will it be possible to draw again?"). During the discussion it turned out that it was possible to find both time and opportunity to draw ("with their own children or nephews", "to buy paint and colouring for adults"). The manifestations of anger had both direct and indirect forms (ironic, sarcastic sayings). The action and expression of experiences are indirect and hidden in the passive form of aggression manifestation but at the same time aimed at meeting personal needs.

This does not mean that it is necessary to get rid of passive forms of anger and aggression. This way of expressing emotions and feelings was formed in personal life experience as the most effective in certain life circumstances. This method allowed the individual to "survive", save own mental and physiological integrity. In certain situations, the personality by using this method, received shelter, escape from a threat (physical, moral, mental and other). It is important for the personality to be aware of circumstances under which he/she uses hidden, passive forms of manifestation of own feelings. It is important to activate individual awareness of own behavioral reactions and find other options of behavior, interaction with other persons.

It was interesting to apply our technique "Wreath of Memories". Performing this technique, participants with multi-coloured ribbons, власні дні народження, прихід весни, нового року, приємні відчуття від “першого снігу”, “літнього теплого дощику”, “весняної відлиги”. Учасниці дивувались, що вони так "розморожувались" під час малювання. Зі слів учасниць "важкі спогади наповнюють їх душу", за таких умов важко радіти простим речам, які відбуваються кожного дня. Спогади з дитинства про "ніжний дотик квітки”, “тепле повітря на обличчі”, відновлювали почуття спокою, почуття психологічного благополуччя. Навіть сам процес малювання повертав до приємних спогадів - для когось “безхмарного дитинства", для інших "підліткові відкриття", "романтичне юнацтво", “перші поцілунки". Спілкування під час малювання провокувало на прояв різних емоцій, негативних у тому числі. Учасниці проявляли злість, що "і тут потрібно боротись за місце на папері". Малюючи святковий стіл, деякі учасниці намагались заповнити все місце на папері, замальовуючи кожен куточок. Їхні коментарі свідчили про високу соціально-ситуативну тривожність - “коли ще буде змога помалювати”. Під час обговорення виявилось, що можна знайти і час, і можливість помалювати ("зі своїми дітьми або племінниками”, “купити фарби і розмальовки для дорослих"). Прояви злості мали як пряму, так і приховану форми (іронічні вислови, саркастичні). Пасивна форма прояву агресії - дія і вираз переживань $є$ непрямими, прихованими, але при цьому спрямованими на задоволення потреб особистості.

Це не означає, що треба позбутись пасивних форм прояву злості, агресії. Цей спосіб прояву емоцій, почуттів був сформований у особистості в їі життєвому досвіді як найефективніший в певних життєвих обставинах. Цей спосіб надав особистості можливість «вижити», зберегти власну психічну та фізіологічну цілісність. В певних ситуаціях особистість, можливо, завдяки цьому способу отримувала прихисток, спасіння від загрози (фізичної, моральної, психічної та іншої). Важливо для особистості усвідомлювати, за яких обставин вона використовує приховані, пасивні форми прояву своїх почуттів. Важливо активізувати усвідомлення особистістю власних поведінкових реакцій і знаходження інших варіантів поведінки, взаємодії з іншими.

Цікавим було проведення нашої методики "Віночок спогадів". Виконуючи іï,, учасниці 


\section{Conditions of effectiveness of methods of supporting women's psychological well-being in situations of temporary relocation}

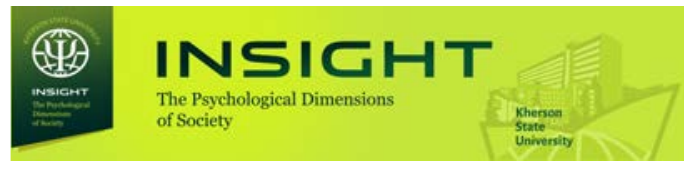

ropes, threads were making a wreath of positive and negative impressions and experiences. The group discussed woven wreaths, colours used, associations that emerged when choosing ribbons. Women liked this task: "it's like embroidery, you pick the colour", "it's nice to take different silk and paper tapes in hands", "when being a schoolgirl, I made appliqués, collages; it was interesting", "the needlework, such as embroidery and knitting, is nice". Pleasant memories arose during and after the exercise. Women came to class the next day, remembering new life stories, new impressions of present life events. Comparing their impressions and impressions of other persons, the women's balance of positive and negative emotions was restored. This is what creates the basis for psychological well-being of personality.

Experiencing well-being is possible under conditions of positive emotional background and positive assessment of reality. When women understand that various life obstacles arise due to our apprehension, it provokes admission of responsibility for overcoming them and building new life prospects. Personality balances between the satisfactions of own needs and needs of others; it is important to maintain a balance between the internal mechanisms of functioning and requirements of the social environment, sociopsychological space. Just depending on the balance creation between desires and possibility of their realization, the personality feels prosperous or not. Overcoming confusion, emotional tension is possible under conditions of actualization of own needs, desires of personality in the process of interaction with other persons.

\section{Conclusions}

Carrying out selected and created techniques confirmed their effectiveness in recovering and maintaining the psychological well-being of women in situation of temporary resettlement.

It is determined that mobilization of women to the direct manifestations of their feelings, desires in dialogue with other persons, which intensifies their implementation, is an important condition for the effectiveness of the applied methods. Awareness and realization of these desires, openness in manifestation of own desires, manifestation of restrained emotions form confidence in relationships with other persons,
3 різнокольорових стрічок, шнурочків, ниток сплітали віночок з позитивних і негативних вражень, переживань. В групі обговорювались сплетені віночки, використані кольори, асоціації, які виникали під час вибору стрічок. Жінкам подобалось таке завдання: "це як вишивання, підбираєш колір”, “приємно брати у руки різні шовкові, паперові стрічки”, “школяркою робила аплікації, колажі, було цікаво”, "рукоділля приємне як вишивання, в'язання”. Приємні спогади виникали впродовж виконання вправи і після неї. Жінки на другий день приходили на заняття, пригадуючи нові життєві історії, нові враження від життєвих подій сьогодення. Порівнюючи свої враження і враження інших, у жінок відновлюється баланс позитивних і негативних емоцій. Саме це створює основу для психологічного благополуччя особистості.

Переживання благополуччя можливе за умов позитивного емоційного фону і позитивної оцінки реальності. Коли жінки розуміють, що різні життєві перепони виникають завдяки нашим уявленням, то це спонукає до прийняття відповідальності за їхнє переборення та побудову нових життєвих перспектив. Особистість балансує між задоволенням власних потреб і потреб інших; важливо підтримувати рівновагу між внутрішніми механізмами функціонування i вимогами соціального оточення, соціально-психологічного простору. Саме від створення балансу між бажаннями і можливостю їхньої реалізації залежить відчуває особистість себе благополучною чи ні. Переборення розгубленості, емоційної напруги можливе за умов актуалізації власних потреб, бажань особистості у процесі взаємодії з іншими.

\section{Висновки}

Проведення підібраних та створених методик підтвердило їхню ефективність у відновленні та підтримці психологічного благополуччя жінок, які опинились в умовах тимчасового переселення.

Визначено, що важливою умовою ефективності застосованих методів $€$ налаштування жінок на прямі прояви своїх почуттів, бажань в діалозі з іншими, що активізує їхню реалізацію. Усвідомлення і реалізація цих бажань, відкритість в прояві своїх бажань, прояв отриманих емоцій формує впевненість в стосунках 
help to save their own mental and physiological integrity.

It is important for recovery and support to the psycho-emotional state of women in temporary resettlement, inclusion in the norms, rules of life of the society, on the one side; and orientation to own needs and values, on the other side. Efforts directed to balance adaptation to norms, requirements of the social environment and satisfaction of own needs to form the psychological well-being of personality. Direct manifestation of emotions, clear and clearly directed action, expression of emotions, wherein desire or unwillingness is laid down (I want, I do not want, I love, I am angry, etc.) becomes important. The obtained empirical results of the research will contribute to effective organization of psychological support. The results of the research may be of interest to managers of rehabilitation programs and psychological assistance centers for women temporary resettlement, as well as to researchers in the field of psychotherapy and psychological counseling.

The study prospect will be application of family group therapy techniques, since the issue of identifying and differentiating the leading factors that determine the state of subjective psychological well-being in the family is not fully explored.

\section{References}

Balabanova, L. M. (2017). Psychological features of reflection of internally displaced persons. Problems of extreme and crisis psychology, 22, 51-59.

Kisarchuk, Z. H., Omelchenko, Ya. M., Lazos, H. P., Lytvynenko, L. I. \& Tsarenko, L. H. (2017). Psychological support to victims of traumatic crisis events: Guidance manual. Kyiv: Lohos.

Kovalenko, A. B. (2017). Social identity as a mechanism of adaptation of personality during social crisis. Ukrainian Psychological Journal, 1, 48-62.

Lebedeva, N. M. \& Ivanova, E. A. (2004). Gestalt Travel: Theory and Practice. St. Petersburg: Rech.

McMallin, R. (2001). Cognitive Therapy Workshop. St. Petersburg: Rech.

Newfeld, G. (2012). Keys to the Well-being of Children and Adolescents. Moscow: Resurs.

Pezeshkian, Kh. (1999). Transcultural Psychotherapy in Russia. Moscow Psychotherapeutic Journal, 3-4, 47-74.

Serdyuk, L. Z. (2017). Structure and function of psychological well-being. Current problems of psychology, 17 (5), 124-133.

Shamionov, R. M. (2012). Psychology of subjective
3 іншими, допомагає зберегти власну психічну та фізіологічну цілісність.

Для відновлення та підтримки психологічного благополуччя жінок, які опинились в умовах тимчасового переселення, важливо, з одного боку, дотримання норм життя соціуму, а з іншого боку, орієнтація на власні потреби і цінності. Намагання врівноважити адаптацію до норм, вимог соціального оточення і задоволення власних потреб формують психологічне благополуччя особистості. Важливим стає прямий прояв емоцій, ясна і чітко спрямована дія, вираз емоцій, в якому закладене бажання або небажання (хочу, не хочу, люблю, злюсь та інше). Отримані емпіричні результати дослідження сприятимуть ефективній організації психологічної підтримки. Результати дослідження можуть бути цікавими керівникам програм реабілітації та центрів психологічної допомоги жінкам, що опинились в умовах тимчасового переселення, а також дослідникам у галузі психотерапії та психологічного консультування.

Перспективою дослідження буде вивчення застосування методів сімейної групової терапії, оскільки не до кінця вивченим залишається питання визначення і диференціації ведучих факторів, що визначають стан суб’єктивного психологічного благополуччя в сім'ї.

\section{Список використаних джерел}

Балабанова Л.М. Психологічні особливості рефлексії вимушених переселенців. Проблеми екстремальної та кризової психології. Вип. 22. Київ: 2017. С. 51-59.

Психологічна допомога постраждалим внаслідок кризових травматичних подій. Метод. посібник / З. Г. Кісарчук, Я.М. Омельченко, Г.П. Лазос, Л.І. Литвиненко, Л.Г. Царенко та ін. Київ: Логос 2017. 207 с.

Коваленко А.Б. Соціальна ідентичність як механізм адаптації особистості під час суспільної кризи. Український психологічний журнал, 1, 2017. C. $48-62$.

Лебедева Н.М., Иванова Е.А. Путешествие в гештальт: теория и практика. СПб.: Речь, 2004, 560 c.

МакМаллин Р. Практикум по когнитивной терапии: Пер. с англ. Спб.: Речь, 2001, 560с.

Ньюфилд Г. Ключи к благополучию детей и подростков. - Ресурс, М.:, 2012. 305 с.

Пезешкиан Х. Транскультуральная психотерапия в России. Московский психотерапевтический журнал, 3(4), 1999. С. 47-74. 


\section{Conditions of effectiveness of methods of supporting women's psychological well-being in situations of temporary relocation}

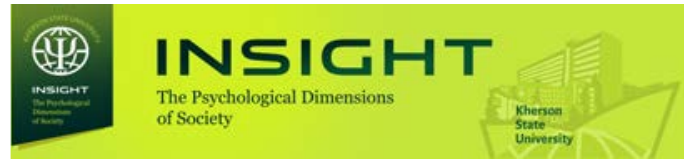

well-being of people. World of Psychology, 2, 143148.

Volodarska, N. (2019). Technologies of psychological well-being formation of personality in crisis situations. In: Modern research of the representatives of psychological sciences (pp.264-283). Lviv-Toruń: Liha-Pres. DOI: 10.36059/978- 966-397-1186/264-282.
Сердюк Л.3. Структура и функція психологічного благополуччя. Актуальні проблеми психологіï, 2017, 17 (5). С. 124-133.

Шамионов Р.М. Психология субъективного благополучия людей. Мир психологии, 2. М.:, 2012. С. 143-148.

Volodarska N. Technologies of psychological well-being formation of personality in crisis situa- tions / Modern research of the representatives of psy- chological sciences: collective monograph / O. Ye. Blynova, Yu. O. Bystrova, I. M. Halian, O. M. Kikinezhdi, etc. Lviv-Toruń: Liha-Pres, 2019, pp. 264-283. DOI: 10.36059/978-966-397-118- 6/264-282. 